\title{
To Build Career Education without borders: from the perspective of the convergence of high school and university
}

\author{
Ning WANG \\ NanJing XiaoZhuang University \\ Nanjing, 211171 China
}

\begin{abstract}
Career Education should be a systematic education process around a person's life career development. Secondary education is called "the crossroads of life and career," the university level is a critical moment for most people change from school to professional people, career education in these two important stages should play an irreplaceable role, and the two career education stage should be organic convergence. Therefore, this study attempts to discuss the establishment of career education system without boundaries from the angle of convergence of high school and university education.
\end{abstract}

Keywords-component; formatting; style; styling; insert (key words) High School; University; convergence; boundaryless career education

\section{INTRODUCTION}

Secondary education is called "personal and professional crossroads", which career education should play an important role. From China's actual situation, whether in junior or senior high school, career education classes are not seen, our career education is only offered to the university. Today, the career college education has become a required course, but the effectiveness of career education plays a very limited role, the employer often criticized for poor career education conducted by the University, and college students often are not satisfied, which has a direct correlation with the failure of building boundaryless career education system of high school and university.

\section{THE NECESSITY OF A BOUNDARYLESS CAREER EDUCATION}

Career education should carry out education, training, mentoring about a person's life, including direct professional competence training and career planning decision-making ability, but also personal and professional awareness, professional roles, career motivation, professional values, internal processes such as changes in the pursuit of professional activities. Career Education rose in the United States in the late 19th century. From a historical point of view, China introduces career education-related content as early as around 1920, but has not been able to sustain a good, long-term implementation. Planned distribution system of employment of graduates makes career education is directly overlooked, Career Education in secondary education is non- existent, so the establishment of a borderless career education system is an urgent need for real.

\section{A. Secondary Educations Is The Foundation And The Beginning Of Career Education}

Although from the viewpoint of time dimension, we can be traced back to the starting point of a career education school, students, in the process of learning and growing, due to the contact with the reality of life, coupled by the school, many families and society will form certain career awareness, career impressions and initial career awareness, but this awareness, impression and perception are often intuitive and emotional. Career education systems bear an important responsibility, not only to help students explore and understand the different occupations; at the same time, help students recognize the relationship between career and learning and help students form a preliminary career planning and decision-making ability, thus guiding students to choose between different disciplines study.

\section{B. College Educations Is A Critical Period To Establish The Status Of Career Education}

If the career education in secondary education is based on the simulation of exploration, then the career stage of university education should focus on the real (practical) nature, which is both the decision of the nature of college education, but also the key to establish their position of the Career Education. From the nature of university education, the college is the final stage of the majority of continuous learning, as well as a critical period of the changing role the school to social person, so university undertakes the task to provide qualified personnel and social development. If you cannot perform this function well, then the university will face what Brubaker said "social and professional circles cast doubt on the reliability of the University." Clearly, the need to eliminate these suspicion universities to train qualified personnel, as UNESCO has the desired "career education pass." Although education career in university level has been more common to carry out, but whether college students or social profession are dissatisfactory with the Career Education of University, so if career Education wants to establish their position, it must be fully implemented and get the recognition and support of students and society at the university level. 


\section{Borderless Convergence Is An Inherent Need For Career Education}

Education system career education is to help student's self-awareness as a starting point, and gradually leads students to pursue professional careers and opposition of life, and thus planning career goals on the basis of establishing the development of their career and ultimately strive to achieve the stated career goals. At present, university education is not practical, many college students are lack of the concepts for career education, the most prominent problem is that college students often do not understand the professionals they chose, nor is the formation of a stable career goals, leading to career education at the university level often aimlessly in the crash. From formal career education activities, the secondary education students is in the "crossroads", need proper guidance and help, so career education should achieve borderless convergence at least from secondary education to university education stage.

\section{LACK AND ANALYSIS OF CAREER EDUCATION IN SECONDARY SCHOOLS AND UNIVERSITIES}

Through depth field investigations in high school and college, interviews found that: The reality is that career education in secondary education in general has not been attracted enough attention to students, schools, parents and the community; and even though it has been generally carried out at the university level, but students, parents and the profession are still very dissatisfied, let alone boundaryless career education.

Career education has carried out after the disappearance of distribution system of graduating college students, it also carried out positive exploration in practice, showing the situation of starting late and rapid development, but due to the traditional educational goals, talents training concept, week sense of market competition, rapid scale expansion of the University of career education and other factors, career education does no find the effective way to serve the career development of college students.

The interface between high school and university education is gradually causing concern, "Twelfth Five-Year Education Plan" repeatedly raised the importance of convergence of high school and college requirements, secondary schools in Beijing, Shanghai, Nanjing carried out the useful exploration, but on the whole, but this exploration is only just beginning.

\section{THE ESTABLISHMENT OF BOUNDARYLESS CAREER EDUCATION SYSTEM BETWEEN HIGH SCHOOL AND THE UNIVERSITY}

Vocational school education is the focus period of career education, but career education is not limited to activities of school education. Construction of boundaryless career Education System between High School and the University is designed to help students to systematically establish the concept of career education, and lay the foundation for lifelong learning for future career development, career education in schools will bring more convenience and advantages. If pupils and students can participate in some professional activities while studying, then this ability and qualifications in many cases are more readily available. "

\section{A. Concept Of Lifelong Career In Education}

Although this paper presents the concept of boundaryless career Education System between High School and the University, career education should be a lifelong concept: career education activities should be ongoing human life, so concept of lifelong career in education should support the career development of a person's life. This paper presents the concept of lifelong career education career because "there is a history of the evolution of life and the direction of events, Integration with personal life, career and life in a variety of roles, which revealed the individual's unique development patterns." So career education should not be limited, to $\mathrm{s}$ guidance and training professional capacity, as the International Commission on Education Development thought: " should not train young people and adults in a specific lifetime unchanged career, but should develop their ability to flow as much as possible in a variety of professional and always stimulate their self-learning and training their own desires."

\section{B. Perfect Curriculum System Of Career Education}

Whether high school or college is to the place of imparting knowledge in the carrier of selection, organization and impartation of knowledge in school is curriculum, if boundaryless career Education System between High School and the University wanted to play a role in the school system, only to establish programs of career education system. From the experience of the United States, Britain, Australia, Japan and other developed countries, career education has entered the "course" of the period. Create a system of career education curriculum system in the school system should be focused on the student's learning characteristics and different learning year segments: high school students are focus on career guidance, the understanding of the relationship between occupation and education (learning), the formation of the initial occupation ideals and career choice; the University is focused on students' professional competence, career aspirations and reality conversion, formation career planning and decision-making ability. The principles to improve career education curriculum system are experiential and practical; and it should form formal and informal curriculum courses, include: career curriculum, professionalism and career planning courses, general professional skills courses, entrepreneurship education, specialized professional competency courses, lifelong learning courses.

\section{To Establish Close Cooperation Between Schools And The Community, Profession}

The training goal of boundaryless career education is to be able to adapt to a variety of job training, career and jobs, career and have self-development capacity of talent. This goal apparently cannot be achieved relying on schools only to provide these opportunities and positions. So, no boundaryless career education need to get, support and cooperation from community, profession; and to provide 
appropriate career guidance and staff for support, to help students better observe and practice in professional understanding and awareness activities, and guide students in career self-development, self-planning and management. Boundaryless career education is a transformative attempts, this reform will not be successful without the assistance of teachers and their active participation, it is necessary to improve interaction and cooperation mechanism for school teachers, community workers, career professionals in schools community, profession, "Double" teachers is the key to establish and nurture the needed talents.

\section{To Promote The Change Of Students' Attitudes And Behavior}

Boundaryless career education is both pointing to the education system between schools and universities, but also pointing to schooling and enter a career without borders, so no boundary career Education System in addition to make career planning and decision-making knowledge, vocational training as a priority, we should also promote education through changing students' attitudes and behaviors as a realistic goal. The change of college students' attitudes and behaviors lies in that students are able to find career goals, planning and career development programs, training professional attitude, professional responsibility and professionalism through career education, form a strong entrepreneurial spirit for future personal career development, good psychological quality perseverance, modest attitude, ambition, etc., in order to maintain lasting and strong motivation for learning for college students in college.

\section{CONCLUSIONS}

Currently, the "new reality" concerned by education sector and profession needs to understand the purpose and structure of career education, and to cultivate the spirit of criticism, reflection and practical ability of students, which proposed new requirements for boundaryless career Education System between High School and the University. Judging from the level of education, secondary schools and universities have a natural connection, as the British biologist Huxley said: "The primary schools and universities, like the Alpha and Omega in educational process ... University is a educational institutions with its own characteristics. ...... Primary and secondary schools is to prepare for entry into university, and university is the top of this building. "In addition to the natural association between high school and college, focusing on the organic link between students' knowledge and ability, teaching and learning should be also attracted more and more attention.

\section{ACKNOWLEDGEMENTS:}

* Fund Project: Jiangsu Provincial Department of Education Philosophy and Social Science Fund Project Name: University of organic link with the secondary research, project number: 2010SJD880044; Nanjing "five" Educational Planning Project, Number: LQ / 2011/002

\section{References}

[1] [US] John - Brubeck. Wang Chengxu translated. Philosophy of Higher Education [M] Hangzhou: Zhejiang Education Press, 2002: 2

[2] The International Committee of the 21st Century Education Division of UNESCO Chinese translation Education: The Treasure Within [M] Beijing: Education Science Press, 1997: 9

[3] Quoted from: Zhang inner collar career: career planning concern steering $[\mathrm{J}]$ education exploration, 201010.

[4] The International Committee of the UNESCO Institute of Education Development edited survival - the world of education today and tomorrow [M] Beijing: Education Science Press, 1997: 14.

[5] Shan Zhonghui. History of educational issues of universities [M] Jinan: Shandong Education Press, 2006: 3 (Foreword) 